Vol. 2, No. 1, Januari - Juni 2018

\title{
edureligia
}

\section{POLITIK DAN PEMILU SERTA IMPLIKASINYA TERHADAP PENDIDIKAN AGAMA ISLAM}

\author{
Lukman Hakim ${ }^{1}$ \\ Universitas Nurul Jadid Probolinggo
}

\section{Info Artikel \\ Sejarah Artikel: \\ Diterima Nopember 2017 \\ Disetujui Desember 2017 \\ Dipublikasikan Januari 2018 \\ Keywords: \\ Islam; Politik; Pemilu; \\ Pemikir Muslim Modern; \\ Kebijakan Politik \\ Pendidikan Agama Islam}

\begin{abstract}
Diskursus tentang Islam dan Politik apabila dikaitkan dengan penerapan demokrasi di Indonesia selalu hangat untuk diperbincangkan. Kajian mengenai hubungan Islam dan politik ini oleh penulis ditekankan pada tiga hal, antara lain (1) konsep politik dalam Islam serta aplikasinya dalam Pemilihan Umum (Pemilu) dan, (2) mengungkap macam-macam pandangan pemikir modern mengenai sistem pemerintahan dan kenegaraan dalam Islam. (3) Kebijakan Politik dan Pemilu serta implikasinya terhadap pendidikan Islam di Indonesia. Dalam pelaksanaannya penelitian ini, karena bahan-bahan pokok atau datadata pokok yang dipakai adalah pemikiran-pemikiran atau wacana-wacana tertulis maka penelitian ini adalah penelitian library research. Ada beberapa argumentasi rasional dalam mewujudkan partai Islam. Pertama, partai merupakan lembaga yang konstitusional dalam menyalurkan aspirasi politik umat. Kedua, adanya realitas akidah yang mengharuskan seorang Muslim untuk menjalankan kehidupan secara Islami. Implikasi politik terhadap penerapan Pendidikan Agama Islam (PAI) di Indonesia terbagai atas tiga fase. Pertama PAI masa orde lama, orde baru dan orde reformasi. Saat ini penerapan $P A I$ di sekolah umum sudah lumayan mendapat tempat tersendiri dalam Undang-Undang Sisdiknas No. 20 tahun 2003 dan Peraturan Pemerintah No. 19 tahun 2005 tentang Standar Nasional Pendidikan dan Peraturan Menteri Pendidikan Nasional No. 22 tahun 2006 tentang Standar Isi untuk Satuan Pendidikan Dasar dan Menengah.
\end{abstract}

Korespondensi:

${ }^{1}$ Universitas Nurul Jadid, Paiton Probolinggo

Email:el.hakim10@mail.com
ISSN 2549-4821

E-ISSN 2579-5694 


\section{PENDAHULUAN}

Dokumen ini merupakan template untuk versi word (.doc) yang dapat digunakan sebagai referensi dalam menulis manuscript anda. Keseluruhan naskah ditulis dengan Calisto 10.

Diskursus yang hingga kini tetap hangat untuk diperbincangkan adalah mengenai apakah ada hubungan antara Islam dan politik. Hal ini menjadi sangat urgen karena dikaitkan dengan maraknya diskusi-diskusi mengenai bentuk demokrasi, sebuah tipologi bentuk sistem pemerintahan yang dipakai oleh negara-negara Barat yang kemudian diterapkan di Indonesia. Padahal Indonesia berpenduduk mayoritas beragama Islam. Pro dan kontra mengenai penerapan demokrasi di Indonesia menjadi agenda penting oleh beberapa organisasi sosial keagamaan maupun organisasi politik yang berbasis Islam (Asmaul, 2015; Ishomuddin, 2010).

Demokrasi merupakan salah satu konsep atau sistem politik. Politik memiliki pengertian dan ruang lingkup tersendiri. Dalam tataran praktis disebut "low politics" yakni politik praktis atau kepartain, dan"high politics" segala bentuk sumbangan pemikiran yang ditujukan untuk memasukkan misi dalam bentuk konsep atau apa saja yang diberikan kepada pemerintah agar pemerintah menjadikan bahan tersebut sebagai pedoman untuk mengambil atau menentukan sebuah kebijakan (Ishomuddin, 2010).

Sebuah pertanyaan yang mengemuka adalah bagaimana hubugan antara Islam dan Politik serta implikasinya dalam penerapan pembelajaran Pendidikan Agama Islam (PAI) di Indonesia. Dari Question Research ini penulis akan mencoba melakukan penelusuran-penelusuran dari berbagai literatur untuk menemukan jawabannya.

Kajian ini ditekankan pada tiga hal, antara lain: (1) konsep politik dalam Islam; (2) mengungkap macam-macam pandangan para pemikir modern mengenai sistem pemerintahan dan kenegaraan dalam Islam, dan (3) kebijakan Politik terhadap pendidikan Islam di Indonesia

Mengingat data-data pokok yang dipakai pada penelitan ini adalah pemikiranpemikiran atau wacana-wacana tertulis maka penelitian ini masuk kategori penelitian library research. Peneliti melakukan penelusuran sumber-sumber pustaka berupa buku-buku, jurnal-jurnal, monograf, dan sumber-sumber lain yang berkaitan dengan fokus penelitian ini. Setelah data terkumpul dianalisis secara kualitatif deskriptif untuk memperoleh dan menarik kesimpulan sebagai jawaban dari research question.

\section{INTEGRASI ISLAM DAN POLITIK}

Perbincangan hubungan Islam dan politik melahirkan aliran-aliran yang saling mengukuhkan pendapatnya satu sama lain. Terdapat tiga aliran tentang hubungan antara Islam dan politik (Ishomuddin, 2013). Aliran pertama berpendirian bahwa Islam bukanlah semata-mata agama dalam pengertian Barat, yaitu hanya menyangkut hubungan manusia dengan Tuhan, sebaliknya Islam adalah agama yang sempurna dan lengkap dengan pengaturan bagi segala aspek kehidupan manusia termasuk kehidupan bernegara.

Aliran kedua, berpendirian bahwa Islam adalah agama dalam pengertian Barat, tidak ada hubungannya dengan kenegaraan. Menurut aliran ini Nabi Muhammad hanyalah seorang Rasul biasa sebagaimana rasul-rasul sebelumnya, dengan tugas tunggal mengajak manusia kembali kepada kehidupan yang mulia dengan menjunjung tinggi budi pekerti luhur; dan Nabi tidak pernah dimaksudkan untuk mendirikan dan mengepalai satu Negara (Harun, 2014; Ishomuddin, 2013).

Aliran ketiga, menolak pendapat bahwa Islam adalah suatu agama yang serba lengkap dan bahwa dalam Islam terdapat sistem ketatanegaraan. Tetapi aliran ini juga menolak anggapan bahwa Islam adalah agama dalam pengertian Barat yang hanya mengatur hubungan antara manusia dan Maha Penciptanya. Aliran ini berpendirian bahwa Islam tidak terdapat sistem ketatanegaraan, tetapi terdapat seperangkat tata nilai etika bagi kehidupan bernegara (Ishomuddin, 2013).

Senada dengal hal ini, sebuah riset yang dilakukan terhadap tiga partai di Indonesia yang berasaskan Islam yaitu Partai Persatuan Pembanguna (PPP), Partai Kebangkitan Bangsa (PKB) dan Partai Amanat Nasional (PAN) menunjukkan bahwa pemahaman tentang agama ketika disandingkan dengan politik menjadi berbeda di antara ketiga parpol tersebut.

Hasil risetnya adalah sebagai berikut: pertama, agama Islam yang satu ketika dimaknai dalam konteks politik di era reformasi ternyata mengalami pemaknaan yang berbeda-beda. Di PPP agama dimaknai sebagai alat pemersatu bangsa dan motivator 
pembangunan. PKB menganggap agama motivator kebangkitan bangsa. Sedangkan di PAN menekankan operasionalisasi nilai-nilai Islam dalam konteks nasional. Kedua, posisi agama dengan politik dalam 3 partai ternyata berbeda-beda (Nurhakim, 2005).

Realitas politik sejauh ini hanya dipahami dengan sangat parsial. Politik hanya diasumsikan sebagai bagian yang tak terpisahkan dari kepentingan, dan area yang strategis untuk menyemai kepentingan itu adalah kekuasaan. Maka paradigma politik menjelma menjadi ungkapan "siapa mendapatkan apa, kapan dan di mana". Dengan demikian realitas politik sangat paradoks dengan pengertian teori normatifnya (Harun, 2014).

Al-Ghazali menungkapkan bahwa agama adalah pondasi, sedangkan kekuasaan adalah penjaganya. Sesuatu yang tidak memiliki pondasi akan roboh dan yang tidak memiliki penjaga akan hilang. Ungkapan ini sinkron dengan pendapat Hasan al-Banna yang menyatakan bahwa tidak ada kebaikan dalam agama jika menegasikan politik, dan tidak ada kebaikan dalam politik jika meninggalkan agama (Harun, 2014).

Pernyataan al-Banna tersebut merupakan konklusi dari pemahaman keagamaan yang integral. Baginya, keberagamaan yang benar dan tepat adalah jika agama selalu menjadi mahaguru dan tujuan berpolitik. Pemahaman ini segaris lurus dengan sikap Islam yang menolak dualisme dan pemisahan agama dengan kekuasaan. Islam tidak mengenal parsialitas ruang antara kerohanian (ruhiyah) yang hanya berkutat dengan urusan-urusan keagamaan dan ruang temporal yang hanya diurus oleh politik (Al-Qardawi, 2006).

Pengertian politik berarti mengatur persoalan umat dan menjaga kemaslahatannya, dan tidak berarti penyesatan, penipuan dan permusuhan. (Al-Khayat, 1999) Dengan demikian, tema sentral politik dalam agama adalah mengatur dan mengarahkan persoalan umat kepada hal yang lebih maslahat sesuai keinginan agama. Di sinilah Ibn Uqail mengungkapkan bahwa perilaku politik harus selalu mendekatkan manusia kepada yang ashlah (right) bukan fasad (disright), meskipun tidak dilakukan Rasul dan tidak dijelaskan secara literal oleh wahyu.

Jika substansi politik demikian, berarti politik memiliki tugas yang sangat mulia, terpuji, dan terhormat, karena berpolitik merupakan bagian dari intrumen keberagamaan dalam merealisasikan ajarannya. Ini artinya, politik menjadi keharusan bahkan kewajiban bagi setiap penganut agama (Islam), karena dalam menerjemahkan ajaran dan titah Tuhan, ada yang mesti menggunakan kekuasaan. Dan cara yang elegan dan konstitusional dalam merangkul kekuasaan itu adalah mutlak dengan politik (Harun, 2014).

Fahmi Huwaidi dalam beberapa tulisannya yang sempat dilarang oleh pemerintah Mesir (al-Maqalat al-Mahzurah) menulis sebuah judul Dharurat al-Hizb al-Islamy (signifikansi partai Islam). Menurut dia, ada beberapa argumentasi rasional dalam mewujudkan partai Islam. Pertama, partai merupakan lembaga yang konstitusional dalam menyalurkan aspirasi politik umat (Huwaidi, 1999).

Kedua, adanya realitas akidah yang mengharuskan seorang Muslim untuk menjalankan kehidupan secara Islami. Cara tepat untuk merealisasikannya adalah ketika dipayungi hukum dan undang-undang. Dan partai merupakan bentuk yang bisa mangakomodasi kepentingan ini.

Ketiga, pekerjaan politik merupakan bagian yang tak terpisahkan dari pemahaman keberagamaan Islam. Seorang Muslim yang benar adalah ketika pengetahuan agama digunakan untuk kehidupan dunianya. Keempat, realitas demokrasi yang tertuang dalam undang-undang yang berdiri atas dasar 'hak mayoritas dan mengakui minoritas (Huwaidi, 1999).

Maka menjadi kelaziman bagi seorang Muslim untuk mengagamakan politik, dalam arti menjadikan politik sebagai kuda dalam mewujudkan ajaran agama, bukan justru sebaliknya, menjadikan politik sebagai agama yang segalanya dipolitisasi sesuai selera, termasuk dogma agama. Jika itu yang yang terjadi, maka akhirnya kita hanya menyaksikan drama politik 'iblis' yang berjubah agamawan atau agamawan yang berhati 'iblis' (Harun, 2014).

\section{ISLAM DAN DEMOKRASI}

Berbicara mengenai politik, tidak bisa dilepaskan dengan sistem pemerintahan dan kenegaraan. Dalam berbagai literatur telah menunjukkan bahwa banyak lahir pemikirpemikir politik modern dari kalangan Islam. Terdapat tiga hal yang melatarbelakangi munculnya pemikiran politik modern (kontemporer) pada akhir abad $19 \mathrm{M}$. Pertama, kemunduran dan kerapuhan dunia Islam yang karena sebab-sebab internal yang mengakibatkan munculnya gerakan pembaruan dan pemurnian. Kedua, 
rongrongan Barat pada kekuasaan politik dan wilayah dunia Islam yang berakhir dengan dominasi atau penjajahan oleh Dunia Barat atas sebagian besar wilayah Islam. Ini mengakibatkan rusaknya hubungan antara Islam dan Barat, dan berkembangnya sikap anti Barat dari umat Islam. Ketiga, keunggulan dunia Barat dalam ilmu, teknologi dan organisasi (Sjadzali, 1993).

Beberapa pemikir Islam modern yang mengemuka di antaranya Jamaluddin alAfgani, ia menghendaki reformasi dan pembaruan politik Islam yaitu dengan mengganti bentuk khilafah menjadi republik. Baginya, kebangkitan dan reformasi umat Islam terletak pada permasalahan politik, yakni kebebasan dari kungkungan kolonial. Islam memberikan ikatan yang umum dan teramat fundamental dan merupakan basis bagi solidaritas umat Islam (Esposito, 1990).

Selanjutnya Muhammad Abduh (1849-1905) berpendapat jika sistem khalifah masih tetap menjadi pilihan model pemerintahan, maka harus bersifat dinamis yakni mengikuti perkembangan masyarakat dalam kehidupan materi dan kebebasan berpikir. Hal ini supaya umat Islam mampu mengantisipasi dinamika zaman (Azhar, 1996).

Tokoh berikutnya adalah Rasyid Ridha (1865-1935), yang justru cenderung ke arah tradisionalisme daripada modernisme. Baginya, jabatan khalifah merupakan kewajiban syara' yang penting menuju penerapan hukum Islam yang terjamin dan terhindar dari berbagai bahaya (Azhar, 1996).

Rasyid Ridha menerapkan prinsip "delegation of authority" yang merupakan hubungan antara rakyat dengan penguasa tidak dalam kerangka absolut tapi lebih kepada amanat. Hubungan antara rakyat dan wakil rakyat adalah hubungan bahwa kedaulatan umat telah didelegasikan kepada wakil-wakil rakyat bukan utusan-utusan (Syamsuddin, 2001).

Sementara itu, Abu Kalam Azad (1888- 1958) di India mempertahankan "Realisme Tradisional", yakni mendukung bentuk tradisional pemerintahan Islam sebagaimana terwujud dalam pemerintahan aktual, kekhalifahan Turki Usmani. Abu Kalam Azad menyatakan bahwa kekhalifahan sebagai pengganti nabi dalam urusan duniawi, adalah satu-satunya bentuk pemerintahan yang sah.

Tokoh yang agak berbeda adalah Ali Abd Raziq (1888-1966). Dalam bukunya Al-Islam wa Ushul al-Hukm ia memperkenalkan teori yang tidak hanya mengkritik keabsahan kekhalifahan, tapi juga mempertanyakan dasar-dasar kekuasaan Islam. Menurutnya, kekuasaan Nabi Muhammad atas kaumnya hanyalah kekuasaan spiritual (ruhaniah), sumbernya adalah keimanan yang ada dalam hati. Sedang kekuasaan seorang khalifah merupakan kekuasaan fisik yang bersifat jasmaniah tanpa ada sedikitpun hubungan hati nurani (Yusdani, 1997).

Soontak pendapat Abd Raziq yang sangat sekuler ini banyak dikecam oleh kaum intelektual di zamannya. Rasyid Ridha adalah tokoh yang paling keras menentang pendapat sekuler Ali Abd Raziq ini. Konon hal ini disebabkan waktu penerbitan buku tersebut bersamaan dengan diadakannya Muktamar Akbar Islam di Kairo dalam rangka cita-cita menghidupkan kembali lembaga kekhalifahan (Sjadzali, 1993).

Berbeda dengan Ali Abdur Raziq yang memisahkan agama dengan negara, Abul A'la al-Maududi (1903-1979) memunculkan konsep "teodemokrasi". Pokok-pokok pikirannya adalah mengenai negara dan pemerintahan Islam amat lengkap dan rinci. Keyakinan dasa nya adalah, pertama, Islam merupakan suatu agama yang lengkap dan paripurna, mengatur semua aspek kehidupan termasuk politik. Kedua, kedaulatan/kekuasaan tertinggi ada di tangan Allah, sehingga sebagai manifestasinya manusia dan negara harus tunduk kepada alQur'an dan Sunnah Nabi. Ketiga, sistem politik Islam yaitu sistem universal yang tidak mengenal ikatan/batasan geografi, bahasa dan kebangsaan (Sjadzali, 1993).

Tokoh terakhir adalah Sayid Qutb (19061966) yang mengangkat konsep "Pandangan Dunia Islam" sebagai Ideologi Islam. Pandanganya mencakup enam prinsip yang terstruktur bagaikan piramida: (a).Ketuhanan dan (b). Doktrin keesaan Tuhan. Empat prinsip lainnya adalah (c). Ketetapan (d). Kesempurnaan (e). Keseimbangan (f). Kepastian dan pragmatisme. Menurut Qutb, karateristik tersebut secara alami bisa dikaitkan dengan asal usul pandangan dunia Islam saat menghadapi atau berlawanan dengan ideologi yang bertentangan (Syamsuddin: 2001).

\section{PEMILU DAN KEBIJAKAN POLITIK DI INDONESIA SERTA IMPLIKASINYA TERHADAP PENDIDIKAN AGAMA ISLAM}


Pada bulan Juni 2017 lalu, KPU meluncurkan Pemilihan Kepala Daerah dan Wakil Kepala Daerah (Pilkada) Tahun 2018. Pilkada Tahun 2018 merupakan Pilkada gelombang ketiga yang diselenggarakan secara serentak. Gelombang pertama dan kedua dilaksanakan pada 2015 dan 2017.

Dasar hukum pelaksanaan Pilkada Serentak ini adalah Undang-Undang Nomor 1 Tahun 2015 tentang Penetapan Peraturan Pemerintah Pengganti Undang-Undang Nomor 1 Tahun 2014 tentang Pemilihan Gubernur, Bupati dan Walikota Menjadi Undang-Undang. Setelah itu, undangundang ini pun mengalami perubahan melalui Undang-Undang Nomor 8 Tahun 2015, hingga akhirnya diatur dalam UndangUndang Nomor 10 Tahun 2016.

Pelaksanaan Pilkada Serentak berangkat dari evaluasi pelaksanaan Pilkada sebelumnya. Menurut Titi Anggraini ada tiga hal yang hendak dijawab dari hadirnya Pilkada Serentak, yakni menciptakan penyelenggaraan pemilu yang efisien dan efektif, memperkuat drajat keterwakilan antara masyarakat dengan kepala daerahnya, dan menciptakan pemerintahan daerah yang efektif serta efisien dalam rangka menegaskan sistem pemerintahan presidensialisme (Aggraini, 2016).

Gelombang pertama Pilkada Serentak dilaksanakan pada tanggal 9 Desember 2015. Pilkada serentak gelombang pertama ini dilaksanakan untuk memilih kepala daerah dan wakil kepala daerah yang akhir masa jabatan (AMJ) 2015 dan Januari s/d Juni 2016. Pilkada Serentak ini dilaksanakan di 269 daerah yang terdiri atas 9 Provinsi, 36 kota, dan 224 kabupaten. Artinya, sekitar 53 persen dari total 537 jumlah provinsi dan kabuptan/kota di Indonesia.

Gelombang kedua Pilkada Serentak dilaksanakan pada tanggal 17 Februari 2017. Pilkada serentak ini dilaksanakan untuk memilih kepala daerah dan wakil kepala daerah yang akhir masa jabatan (AMJ) Juli s/d Desember 2016 dan 2017. Pilkada Serentak ini dilaksanakan di 101 daerah yang terdiri atas 7 Provinsi, 18 kota, dan 76 kabupaten.

Pilkada Serentak 2017 sangat menyita perhatian publik khususnya pelaksanaan pemilihan Gubernur dan Wakil Gubernur DKI Jakarta yang berlangsung 2 putaran (UU Khusus untuk DKI).

Pilkada Serentak 2015 dan 2017 telah berlangsung dengan aman, lancar, tertib, dan damai. Penyelenggaraannya sukses. Partisipasi pemilih memang belum memenuhi target KPU, yakni 77,50 persen. Partisipasi pemilih Pilkada Serentak 2015 adalah 69,14 persen dan 2017 sebesar 74,20 persen. Partisipasi ini masuk kategori moderat atau sedang (Aggraini, 2016).

Catatan lain keberhasilan penyelenggaraan Pilkada Serentak 2015 dan 2017 adalah transparansi hasil pemungutan suara di TPS dan minimnya sengketa di MK. KPU Kabupaten/Kota dapat merampungkan scan salinan C1 mencapai 100 persen dalam waktu $1-3$ hari, bahkan di sejumlah daerah tidak samapi 1 hari. Sengketa Perselisihan Hasil Pemilu (PHP) ke MK, sebagian besar tidak dapat diterima dan ditolak MK.

Gelombang ketiga Pilkada Serentak akan dilaksanakan pada tanggal 27 Juni 2018. Pilkada serentak gelombang ketiga ini dilaksanakan untuk memilih kepala daerah dan wakil kepala daerah yang akhir masa jabatan (AMJ) 2018 dan 2019. Ada 171 daerah yang akan melaksanakan Pilkada Serentak di tahun 2018 yang terdiri atas 17 Provinsi, 39 kota, dan 115 kabupaten (Aggraini, 2016)

Saat makalah ini ditulis, sedang berlangsung Pilkada Gubernur dan Wakil Gubernur Jawa Timur yang menyajikan kontestasi antara pasangan nomor urut 1 Khofifah Indar Parawansa-Emil Dardak unggul dari pasangan nomor urut 2 Saifullah Yusuf (Gus Ipul)-Puti Guntur Soekarno. Pada sejumlah survei, Khofifah-Emil memang menang, tapi ada pula survei yang memenangkan Gus IpulPuti. Namun dari hasil quick count pasangan Khofifah-Emil mengungguli Gus Ipul-Puti.

Dari beberapa hasil quick count tersebut berdasarkan data detik.com diantaranya:

SMRC (suara terkumpul 99,75\%) 1. Khofifah Indar Parawansa-Emil Dardak: $52,28 \%$

2. Saifullah Yusuf-Puti Guntur Soekarno: $47,72 \%$

LSI (suara terkumpul 100\%)

1. Khofifah Indar Parawansa-Emil Dardak: $54,29 \%$

2. Saifullah Yusuf-Puti Guntur Soekarno: $45,71 \%$

Charta Politika (suara terkumpul 100\%)

1. Khofifah Indar Parawansa-Emil Dardak: $53,54 \%$

2. Saifullah Yusuf-Puti Guntur Soekarno: $46,46 \%$ 
Hasil definitifnya masih menunggu proses real count di KPU Jawa Timur, apabila hasil real count sama dengan kebanyakan hasil quick count, maka tercipta sejarah baru untuk pertama kalinya Jawa Timur dipimpin oleh seorang Gubernur perempuan.

Indonesia adalah Negara demokrasi, bukan Negara teodemokrasi sebagaimana konsep kenegaraan menurut Al Maududi. Meskipun Indonesia bukanlah Negara Islam namun mayoritas penduduknya adalah muslim. Dalam konteks pendidikan Islam Indonesia, setelah proklamasi kemerdekaan, pemerintah membentuk Departemen Agama yang memegang kewenangan utama dalam penyelenggaraan bidang agama. Salah satu bentuk kewenangan tersebut adalah terkait dengan pengembangan institusi pendidikan Islam. Namun, kewenangan Departemen Agama yang terkait dengan pendidikan Islam telah melahirkan sejumlah kebijakan yang berimplikasi pada kultural dan politis.

Secara kultural, pendidikan Islam dalam bentuk pesantren di Jawa, maunasah di Aceh, Surau di Minangkabau dan madrasah sebagai lembaga pendidikan Islam. Lembagalembaga tersebut telah mengalami proses transformasi keilmuan dan kelembagaan adalah lembaga pendidikan Islam yang telah menyejarah. Usia pendidikan Islam lebih tua dari kemerdekaan RI sehingga tidak dapat dipisahkan dari kultur bangsa ini (Hamlan, 2013; Harun, 2014).

Dari tiga jenis lembaga pendidikan yang kini berkembang di Indonesia, pesantren-sekolahmadrasah, hanya pesantren yang berakar dari tradisi asli (indigenous) Nusantara (Asrohah, 2004; Dhofier, n.d.; Van Bruinessen, 1999). Sedangkan sekolah dan madrasah yang muncul belakangan, lahir dari hasil interaksi dengan pihak luar. Sekolah dikenal setelah adanya "interaksi" bangsa Indonesia dengan kaum penjajah, sedangkan madrasah lahir sebagai respon umat Islam di Indonesia atas gerakan pembaharuan Islam di Timur Tengah sekaligus sebagai counter institution terhadap lembaga sekolah bentukan penjajah.

Pasca Indonesia merdeka pemerintah menetapkan sejumlah kebijakan politik pendidikan di mana secara fungsional umat Islam mendapatkan manfaat atas kebijakan politik pendidikan pemerintah, terutama bagi pengembangan dan peningkatan mutu pendidikan Islam. Atas dasar ini lahir berbagai kebijakan negara tentang sistem pendidikan nasional yang memuat tentang relasi antara pendidikan Islam dalam sistem pendidikan nasional, di antaranya lahir
Undang-Undang Nomor 4 tahun 1950 Jo. Nomor 12 tahun 1954 tentang Pendidikan dan Pengajaran di Sekolah, Undang- Undang Nomor 2 tahun 1989 tantang Sistem Pendidikan Nasional dan Undang-Undang Nomor 20 tahun 2003 tantang Sistem Pendidikan Nasional. Dalam Undangundang tersebut posisi pendidikan Islam mengalami perubahan sesuai dengan pengaruh kepentingan oleh pemangku kepentingan dalam pengambilan keputusan kebijakan negara tentang sistem pendidikan nasional (Hamlan, 2013).

Di masa awal berdirinnya negara 1945-1966, pertentangan antara kepentingan politik dan aliran ideologi nasionalis sekuler dan nasionalis Islam acap kali terjadi dalam memutuskan kebijakan. Keadaan yang demikian berimplikasi terhadap kebijakan pemerintah yang belum mencerminkan pendidikan Islam sebagai lembaga pendidikan yang terintegrasi ke dalam sistem pendidikan nasional. Pendidikan Islam sepenuhnya di bawah tanggung jawab Departemen Agama yang dibentuk untuk membidangi masalah-masalah keagamaan.

Perdebatan-perdebatan antara kelompok Muslim yang beraliran politik dan ideologi yang agamis (Islam) berpandangan bahwa agama dan negara tidak dapat dipisahkan dan menuntut Islam dijadikan sebagai dasar negara apabila Indonesia merdeka, sedangkan golongan nasional dalam aliran politik dengan ideologi sekulernya menghendaki Pancasila sebagai dasar negara (Hamlan, 2013; Harun, 2014; Ishomuddin, 2010).

Ditinjau dari perspektif kehidupan kenegaraan, muara dari keinginan dan upaya pemikir dan aktivis politik Islam adalah menempatkan posisi Islam secara pas dalam kehidupan kenegaraan, yaitu dengan menjadikan Islam sebagai dasar negara. Muhammad Natsir selaku tokoh Masyumi merupakan salah seorang artikulator penting dari gagasan ini. Bahkan, sebelum Indonesia merdeka, pada tahun 1930-an, Natsir telah terlibat dalam perdebatan dengan Soekarno tentang hal krusial tersebut (Kosim, 2006).

Gagasan menjadikan Islam sebagai dasar negara kembali mewacana dalam sidang Badan Pelaksana Usaha Persiapan Kemerdekaan Indonesia (BPUPKI). Perdebatan itu berakhir tanggal 22 Juni 1945 setelah adanya kompromi dan kesepakatan, yaitu kelompok Islam agamis, nasionalis dan kelompok nasionalis sekuler berkaitan dengan dijadikannya Piagam Jakarta sebagai 
Mukadimah UUD 1945. Namun, pada tanggal 18 Agustus 1945, kesepakatan itu berubah dengan penerimaan rumusan Pancasila tanpa disertai Piagam Jakarta. Perubahan itu diterima oleh kelompok Islam yang berideologi agamis, karena situasi saat itu mengharuskan adanya prioritas pilihan (Kosim, 2006).

Perubahan atas dasar negara tersebut didasarkan pada pertimbangan politis untuk persatuan dan kesatuan bangsa. Namun, proses perubahannya dalam sidang PPKI tanggal 18 Agustus 1945 berlangsung dalam waktu yang sangat singkat. Perubahan dasar negara itu menimbulkan pertanyaan umat Islam dan perasaan tidak puas, karena Piagam Jakarta telah disepakati sebelumnya yang mencantumkan syariat Islam sebagai dasar negara sebagaimana yang tercantum dalam Piagam Jakarta.

Dalam perkembangan selanjutnya, untuk meredam keinginan umat Islam setelah Indonesia merdeka, pemerintah menyediakan pembentukan Departemen Agama pada tanggal 3 Januari 1946 sebagai konsensi bagi umat beragama khususnya bagi umat Islam. Departemen ini dibentuk untuk melindungi kebebasan beragama, menjaga keserasian hubungan antara kemunitas agama yang berbeda, dan yang utama adalah untuk menangani masalah keagamaan Muslim, seperti pendidikan Islam, perkawinan, haji, dakwah, dan mengelola peradilan agama (Kosim, 2006).

Pada umumnya era Orde Lama dipilah menjadi tiga babakan sejarah; awal kemerdekaan (1945-1950), masa demokrasi liberal (1950- 1959), dan masa demokrasi terpimpin (1959-1965). Periodesasi ini menunjukkan bahwa selama masa Orde Lama, kondisi sosial politik tidak stabil. Ketidakstabilan situasi ini juga berdampak langsung pada perjalanan pendidikan bangsa, termasuk keberadaan pendidikan agama di sekolah umum.

Setelah Indonesia merdeka, segera dilakukan upaya-upaya pembaharuan dalam bidang pendidikan dan pengajaran, dalam rangka menata kualitas SDM yang telah lama tercabik-cabik kaum penjajah. BP KNIP (Badan Pekerja Komite Nasional Indonesia Pusat) dalam sidangnya tanggal 29 Desember 1945 membuat sejumlah rekomendasi kepada Kementerian Pendidikan Pengajaran dan Kebudayaan, yang intinya agar selekas mungkin mengusahakan pembaharuan pendidikan dan pengajaran yang dijalankan sesuai dengan rencana pokok usaha pendidikan dan pengajaran baru (Kosim, 2006).

Tentang pendidikan agama, Panitia Penyelidik merekomendasikan hal-hal berikut: (a) Pelajaran agama dalam semua sekolah diberikan pada jam pelajaran sekolah; (b) Para guru dibayar oleh pemerintah; (c) Pada Sekolah Dasar, pendidikan agama diberikan mulai kelas IV; (d) Pendidikan tersebut diselenggarakan seminggu sekali pada jam tertentu; (e) Para guru agama diangkat oleh Departemen Agama; (f) Para guru agama diharuskan juga cakap dalam pendidikan umum; (g) Pemerintah menyediakan buku untuk pendidikan agama, (h) Diadakan latihan bagi para guru agama; (i) Kualitas pesantren dan madrasah harus diperbaiki, dan (j) Pengajaran bahasa Arab tidak dibutuhkan (Rahim, 2001).

Era Orde Baru ditandai dengan penumpasan PKI dan antek-anteknya setelah mereka gagal melakukan pemberontakan tahun 1965. Dengan tumbangnya PKI, tujuan pendidikan nasional yang sebelumnya cenderung ke kiri diluruskan kembali. Berdasar Tap MPRS Nomor XXVII/MPRS/1966 Bab II Pasal 3, Tujuan Pendidikan Nasional diarahkan untuk "Membentuk manusia Pancasila sejati berdasarkan ketentuan-ketentuan yang dikehendaki oleh Pembukaan dan isi Undang-Undang Dasar 1945" (Aman, 1980). Perhatian bangsa Indonesia akan pentingnya pendidikan agama juga semakin meningkat. Mereka menyadari hanya dengan bekal agama yang kuat paham komunisme akan bisa dihindari.

Masa Reformasi ditandai dengan "kejatuhan" Soeharto pada bulan Mei 1998 setelah 32 tahun berkuasa (1966-1998). Di masa reformasi ini keberadaan pendidikan agama di sekolah semakin tak tergoyahkan. Tap MPR Nomor IV/MPR/1999 tentang GBHN menegaskan agar "Meningkatkan kualitas pendidikan agama melalui penyempurnaan sistem pendidikan agama sehingga lebih terpadu dan integral dengan sistem pendidikan nasional dengan didukung oleh sarana dan prasarana yang memadai" (Kosim, 2006)

Dalam Undang-Undang Nomor 20/2003 tentang Sistem Pendidikan Nasional, posisi pendidikan agama terus dimantapkan. Sebagai tindak lanjut dari Undang-Undang Nomor 20/2003, pemerintah mengeluarkan Peraturan Pemerintah Nomor 19/2005 tentang Standar Nasional Pendidikan. 
Badan Standar Nasional Pendidikan (BNSP) mengusulkan kepada Departemen Pendidikan Nasional, parameter baru penentu kelulusan siswa menyusul polemik ujian nasional. Dalam usulan tersebut dijelaskan, seorang siswa dinyatakan lulus sekolah apabila; (a) telah menyelesaikan seluruh program pembelajaran; (b) memiliki nilai baik dalam empat bidang agama dan akhlak mulia, kewarganegaraan dan kepribadian, estetika, dan kelompok mata pelajaran pendidikan jasmani, olah raga, dan kesehatan; (c) lulus ujian sekolah, dan (d) lulus ujian nasional.38 Dengan demikian, jika usulan ini disepakati Departemen Pendidikan Nasional, posisi pendidikan agama semakin mantap karena menjadi salah satu penentu kelulusan siswa. (Kosim, 2006)

\section{KESIMPULAN}

Islam dan Politik serta aplikasinya dalam Pemilu apabila dikaitkan dengan penerapan demokrasi di Indonesia maka akan menjadi menarik untuk didiskusikan. Tema sentral politik dalam agama adalah mengatur dan mengarahkan persoalan umat kepada hal yang lebih maslahat sesuai keinginan agama. Politik memiliki tugas yang sangat mulia, terpuji, dan terhormat, karena berpolitik merupakan bagian dari intrumen keberagamaan dalam merealisasikan ajarannya. Ini artinya, politik menjadi keharusan bahkan kewajiban bagi setiap penganut agama (Islam), karena dalam menerjemahkan ajaran dan titah Tuhan, ada yang mesti menggunakan kekuasaan. Dan cara yang elegan dan konstitusional dalam merangkul kekuasaan itu adalah mutlak dengan politik.

Saat ini penerapan PAI di sekolah umum sudah lumayan mendapat tempat tersendiri dalam Undang-Undang Sisdiknas No. 20 tahun 2003 dan Peraturan Pemerintah No. 19 tahun 2005 tentang Standar Nasional Pendidikan dan Peraturan Menteri Pendidikan Nasional No. 22 tahun 2006 tentang Standar Isi untuk Satuan Pendidikan Dasar dan Menengah. Pendidikan agama diharapkan dapat menjadi sarana bagi pengembangan pribadi, watak dan akhlak mulia peserta didik, serta pada pembentukan sikap dan perilaku berakhlak. Pengembangan pribadi, watak, dan akhlak mulia, selain dilakukan oleh lembaga pendidikan formal, juga oleh keluarga, lembaga sosial keagamaan, dan lembaga pendidikan tradisional keagamaan serta tempat-tempat ibadah.
Selain itu Badan Standar Nasional Pendidikan (BNSP) mengusulkan kepada Departemen Pendidikan Nasional, parameter baru penentu kelulusan siswa menyusul polemik ujian nasional. Dalam usulan tersebut dijelaskan, seorang siswa dinyatakan lulus sekolah apabila; (a) telah menyelesaikan seluruh program pembelajaran; (b) memiliki nilai baik dalam empat bidang agama dan akhlak mulia, kewarganegaraan dan kepribadian, estetika, dan kelompok mata pelajaran pendidikan jasmani, olah raga, dan kesehatan; (c) lulus ujian sekolah, dan (d) lulus ujian nasional.

\section{DAFTAR PUSTAKA}

Aggraini, T. (2016). Evaluasi Pilkada Serentak 2015. Perludem, April.

Asmaul, H. (2015). Pemikiran Politik Berbasis Islam Humaniter, 4, 493-500.

Asrohah, H. (2004). Pelembagaan Pesantren: Asal-Usul dan Perkembangan Pesantren di Jawa. Jakarta: Bagian Proyek Peningkatan Informasi Penelitian dan Diklat Keagamaan Departemen Agama RI.

Dhofier, Z. (n.d.). Tradisi Pesantren; Studi tentang Pandangan Hidup Kyai. Jakarta: LP3ES.

Hamlan. (2013). Politik Pendidikan Islam dalam Konfigurasi Politik di Indonesia. Hunafa.

Harun, H. (2014). Revitalisasi Peran Politik Umat: Urgensi Integrasi Islam dan Politik dalam Realitas Bernegara. Kontekstualita, 29(1), 85-100.

Ishomuddin. (2010). Hubungan Islam Dan Politik, 6(September), 28-33.

Ishomuddin. (2013). Studi Tentang Wawasan Pengurus Dan Simpatisan Partai Politik Berasas Islam Di Malang Raya Political Understanding Islam Study on the Management Insights and Investigators Political Parties berasas Islam in Malang Di dalam wacana keIslaman terdapat perbeda, 8, 21-29.

Kosim, M. (2006). Pendidikan Agama Islam Di Sekolah Umum (Perspektif SosioPolitik-Historis). Tadris, 1 .

Nurhakim, M. (2005). Pemaknaan Agama dalam Parta Politik dalam Konteks Reformasi, Studi banding PPP,PKB, PAN. 
Rahim, H. (2001). Arah Baru Pendidikan Islam di Indonesia. Jakarta: Logos.

Van Bruinessen, M. (1999). Kitab Kuning, Pesantren, dan Tarekat: Tradisi-Tradisi Islam di Indonesia. Bandung: Mizan. 